\title{
Educating and Inspiring Young People for the Next Generation of Exploration
}

\author{
Robert C. Armstrong, Jr. Deputy Manager \\ Integration Office \\ Exploration Launch Projects Office \\ NASA Marshall Space Flight Center \\ Huntsville, AL 35812
}

\begin{abstract}
With the graying of the nation's scientific workforce and the decline in students pursuing science, technological, engineering, and math related-studies, real challenges lie ahead if America is to continue to sustain the Vision for Space Exploration in the foreseeable future. Likewise, challenges exist in the economic arena as the United States seeks to maintain its preeminence among the technological leaders of the world. Currently, less than $6 \%$ of high school seniors are pursuing engineering degrees, down from $36 \%$ a decade ago. ${ }^{1}$ Today, China produces six times as many engineers as does the United States and Japan, at half our population, develops twice as many engineers. Despite spending more per capita on public education than any other nation, except Switzerland, ${ }^{2}$ U.S. students of high school age are failing to compete with many foreign countries. ${ }^{3}$ These trends do not bode well for America's future competitiveness in space and other technically driven areas, such as defense.
\end{abstract}

Like many aerospace organizations, NASA and its industry partners are seeking qualified future workers for an upcoming array of wide-ranging space missions (see Figure 1). Using the activities of the Vision for Space Exploration as a springboard for inspiration, NASA encourages the next generation of engineers and scientists to take this nation to the Moon, Mars, and beyond. The Exploration Launch Projects (ELP) Office, located at NASA's Marshall Space Flight Center, recognizes the critical need for a new generation of engineers and scientists as more than just an Agency problem, but as an impending national crisis that will impact America's competitiveness and technological leadership. In the 1960s, the Apollo missions inspired thousands of young people to enter technical fields-we believe space exploration can continue to provide that motivation. ELP, in cooperation with NASA's Education Office and Marshall's Office of Academic Affairs, is developing strategies to reach targeted audiences with focused messages to develop interest in science, technical, engineering, and mathematics (STEM) among students from elementary schoolaged children through high school. An important part of this effort is to also educate students and their teachers on the technological benefits derived from space-related activities. 


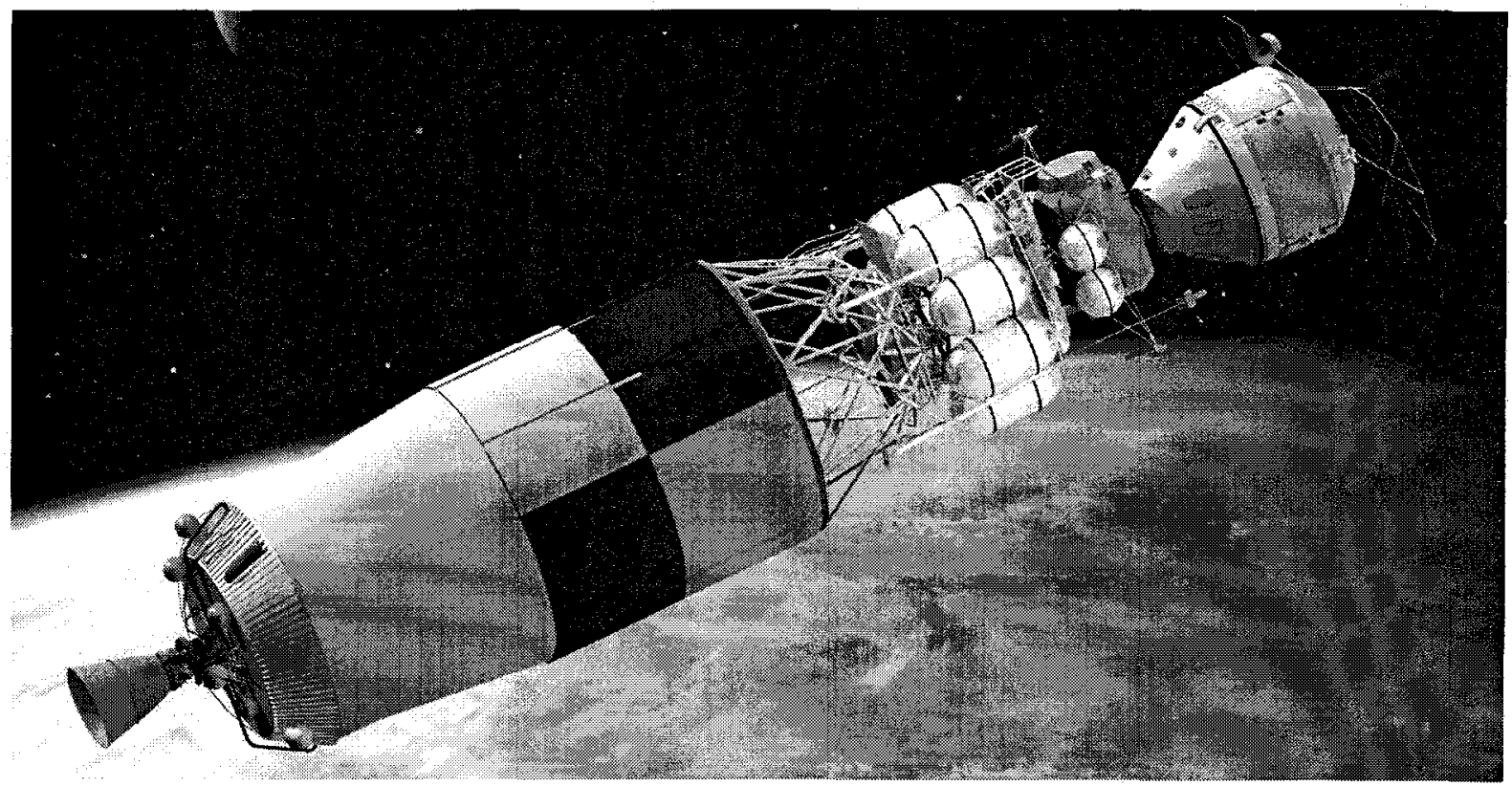

Figure 1. The Ares V Earth Departure Stage will transport the Lunar Surface Access Module and the Orion Crew Exploration Vehicle to lunar orbit (artist's concept).

In addition to traditional classroom curriculum, NASA is using leading-edge, highly visible venues for sharing space exploration messages, including the Internet, podcasts, and live events. Through strategic partnerships with educational institutions and private industry, NASA is developing new, engaging methods of public outreach, such as interactive lunar mission electronic kiosks, videos for teachers and students, learning materials, podcasts, interactive educational games, and question-andanswer teleconferences with NASA engineers and scientists via NASA's Digital Learning Network. An interactive kiosk being developed in cooperation with industry partners will simulate an entire lunar mission, from launch through recovery. To understand the needs of educators better, ELP is conducting focus groups with teachers at multiple grade levels to determine their needs and understand the most effective methods for teaching children and young people about space exploration. These sessions are already bearing fruit, as NASA has begun developing and modifying existing classroom materials based on teacher feedback to ensure the lessons are aligned with state and national standards and easily implemented into classroom instruction. ELP has developed curriculum and classroom products that tie directly to NASA's strategic Vision for Space Exploration.

In the future, NASA will continue to create additional materials on a continuing basis, such as posters, fact sheets, games, and activities that attract the next generation to STEM. Additionally, ELP, in cooperation with Headquarters and other NASA Centers, is conducting more active public outreach efforts by providing engaging, well-informed speakers at local, regional, and national events such as science and technology trade shows, job fairs, and school activities not normally associated with space, such as college football games. These efforts include supporting efforts such as the Student Launch Initiative, where students from middle school up to college spend 9 months designing and building a rocket that flies up to 1 mile in altitude while transporting a scientific payload. Through this integrated, multimedia approach, NASA hopes to reach students with engaging approaches that encourage them to take the educational steps they need to grow the nation's 
technical capabilities and to become excited about contributing to the next great frontier of space exploration.

\footnotetext{
${ }^{1}$ Wallace, Kathryn. "America's Brain Drain Crisis: Why Our Best Scientists are Disappearing and What's Really at Stake." Readers Digest, December 2005.

2 "Educational Expenditure per Student." Education at a Glance 2006 Tables. http://www.oecd.org/document/6/0,2340,en $264934515 \quad 37344774 \quad 1$ l 1 1 $1,00 . h t m l$.

3 "Higher Education in Science and Engineering," Science and Engineering Indicators 2006. http://www.nsf.gov/statistics/seind06/c2/c2h.htm.
} 


\title{
Educating and Inspiring Young People \\ for the Next Generation of Exploration
}

\author{
Robert C. Armstrong Jr. \\ Deputy Manager \\ Project Integration \\ Exploration Launch Projects Office \\ NASA Marshall Space Flight Center \\ Huntsville, AL 35812
}

\begin{abstract}
With the graying of the nation's scientific workforce and the decline in students pursuing science, technological, engineering, and math related-studies, real challenges lie ahead if America is to continue to sustain the Vision for Space Exploration in the foreseeable future. Likewise, challenges exist in the economic arena as the United States seeks to maintain its preeminence among the technological leaders of the world. Currently, less than 6 percent of high school seniors are pursuing engineering degrees, down from 36 percent a decade ago. ${ }^{1}$ Today, China produces six times as many engineers as does the United States and Japan, at half our population, develops twice as many engineers. Despite spending more per capita on public education than any other nation, except Switzerland, ${ }^{2}$ U.S. students of high school age are failing to compete with many foreign countries. ${ }^{3}$ These trends do not bode well for America's future competitiveness in space and other technically driven areas, such as defense.
\end{abstract}

$\begin{array}{ll}A A O & =\text { Academic Affairs Office } \\ D o E & =\text { Department of Education } \\ E D C & =\text { Engineering Design Challenge } \\ E L P & =\text { Exploration Launch Projects } \\ E R C & =\text { Educator Resource Center } \\ F I R S T & =\text { For Inspiration and Recognition of Science and Technology } \\ I C E & =\text { Interactive Constellation Experience } \\ I C O N & =\text { Interactive Concepts of Operations } \\ K & =\text { Kindergarten } \\ M S F C & =\text { Marshall Space Flight Center } \\ N A S A & =\text { National Aeronautics and Space Administration } \\ N S F & =\text { National Science Foundation } \\ S L I & =\text { Student Launch Initiative } \\ S T E M & =\text { Science, Technology, Engineering, and Mathematics } \\ T A R C & =\text { Team America Rocket Challenge }\end{array}$

\section{Introduction: The Crisis in Aerospace}

Like many aerospace organizations, NASA and its industry partners are seeking qualified future workers for an array of wide-ranging space missions (see Figure 1). Using the activities of the Global Exploration Strategy ${ }^{4}$ as a springboard for inspiration, NASA is encouraging the next generation of engineers and scientists to take this nation to the Moon, Mars, and beyond. The Exploration Launch Projects (ELP) Office, which is located at NASA's Marshall Space Flight Center (MSFC) and is responsible for developing the nation's new space transportation 
systems, recognizes the critical need for a new generation of engineers and scientists. This is more than just an agency problem: it is an impending national crisis that will impact America's competitiveness and technological leadership. In the 1960s, the Apollo missions inspired thousands of young people to enter technical fields. Space exploration can continue to provide that motivation.

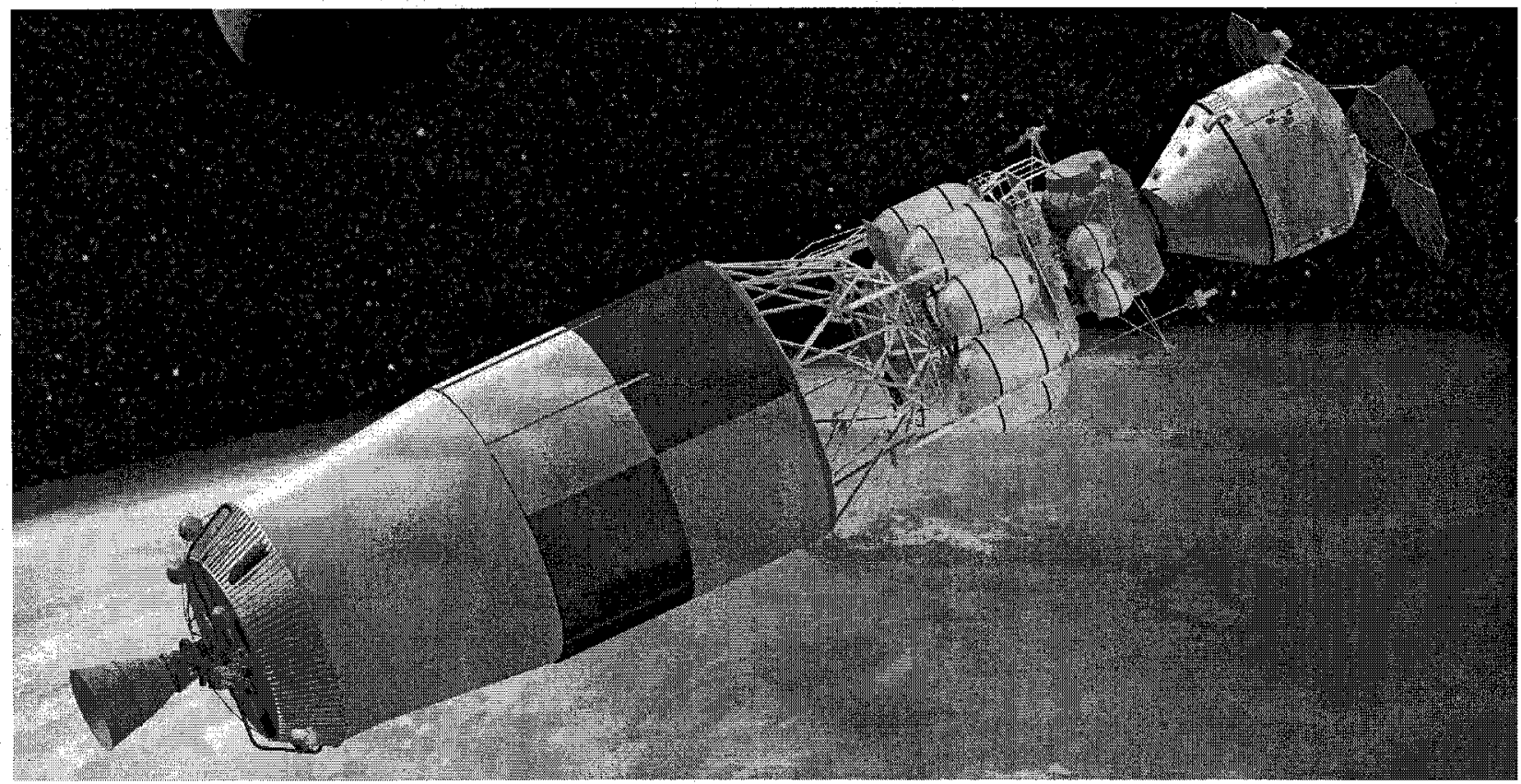

Figure 1. The Ares V Earth Departure Stage will transport the Lunar Lander and the Orion Crew Exploration Vehicle to lunar orbit (artist's concept).

The problem of finding qualified scientists and engineers is not confined to the aerospace industry alone, though it is of primary concern to NASA. John Karas, Vice President of Lockheed-Martin's Human Spaceflight division, noted in a 2007 speech that over 80 percent of aerospace workers are 49 years of age or older. ${ }^{5}$ NASA itself has been concerned by several public reports that have raised the warning about America's competitiveness and have advocated better science, technical, engineering, and mathematics (STEM) education. These reports include Rising Above the Gathering Storm: Energizing and Employing America for a Bright Economic Future by the National Academies; Learning for the Future: Changing the Culture of Math and Science Education to Ensure a Competitive Workforce by the Committee on Economic Development; and Benchmarks of Our Innovation Future by the Taskforce on the Future of American Innovation. They have generated a variety of important findings regarding the U.S. workforce, including those described below.

\section{A. Impact of STEM-Related Activities on U.S. Economy}

Young people studying STEM contribute to more than just NASA's need for aerospace engineers. Science and technology support the high-tech products and services that make America the world's economic powerhouse:

- Economic studies conducted before the information-technology revolution demonstrated that as much as 85 percent of measured growth in U.S. income per capita was due to technological change. ${ }^{6}$

- It has been estimated that the 5 percent of Americans engaged in science and engineering generate as much as 35 percent of U.S. exports. ${ }^{7}$

- Craig Barrett, Chairman of the Intel Corporation, stated recently, "If I take the revenue in January and look again in December of that year 90 percent of my December revenue comes from products which were not there in January."

- The Federal Aviation Administration estimates that the U.S. commercial space transportation business alone, from which NASA procures services, generated over $\$ 100$ billion annually in direct and indirect revenues in $2006^{8}$ 
- On average, each dollar spent on research and development (R\&D) returns about $\$ 9$ in technology-induced economic gain. ${ }^{9}$

- NASA Administrator Michael Griffin has stated that "Both [science and exploration] will contribute greatly to increased understanding of ourselves, the environment in which we live, and the solar system and universe around us."10

\section{B. The Crisis in STEM Education}

Despite the obvious need for STEM-literate students, America's young people have not pursued science and technology-related jobs in the same numbers as in years past, as the following facts demonstrate:

- By 2010 , if current trends continue, more than 90 percent of all scientists and engineers in the world will be living in Asia. ${ }^{11}$

- South Korea, with one-sixth of our population, graduates as many engineers as the United States.

- More than 50 percent of all engineering doctoral degrees awarded by U.S. engineering colleges are to foreign nationals.

- However, security concerns are reducing the number of foreign students available to study and work in the United States, while these students have increasing opportunities to study and work in their home countries and other nations.

- The number of engineering degrees awarded in the United States is down 20 percent from the peak year of 1985.

- Although U.S. fourth graders score well against international competition, they fall near the bottom or dead last by 12 th grade in mathematics and science, respectively. ${ }^{12}$

All of these issues continue to be a problem, even at a time when education spending per student is at record levels. The Department of Education (DoE) has noted that "Total taxpayer investment in [kindergarten through $12^{\text {th }}$ grade] education in the United States for the 20042005 school year [was] estimated to be $\$ 536$ billion, exceeding national defense." ${ }^{\prime 13}$ Despite our nation's massive expenditures per student, more needs to be done to ensure that students learn and achieve.

The DoE has admitted that America's schools are not producing the math excellence required for global economic leadership and homeland security in the $21^{\text {st }}$ century, while "only a quarter of our fourth- and eighthgraders are performing at proficient levels in math. Twelfth-grade math scores have not improved since 1996."14

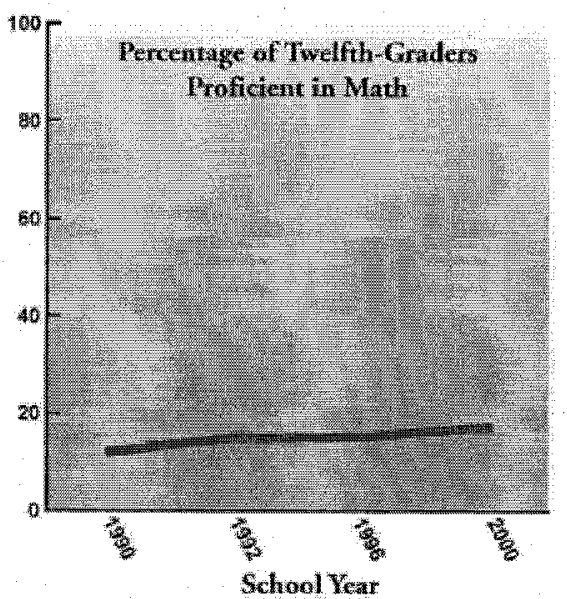

Figure 2. Trends in 12th Grade Math Achievement (Source: U.S. Department of Education).

Other nations are not having these problems. Indeed, their STEM achievers are beginning to overtake the U.S. in numbers of science and engineering degrees:

- About 78 percent of science and engineering doctorates worldwide were earned outside the United States.

- The numbers of natural sciences and engineering doctoral degrees awarded in China, South Korea, and Japan have continued to rise.

- In the late 1990 s and early 2000 s, the numbers of natural science and engineering doctoral degrees leveled off or declined in the United States, the United Kingdom, and Germany. ${ }^{15}$

In short, something needs to be done to ensure America's continued world leadership in science, technology, and economic growth. Education plays a major part in that leadership, and NASA is playing a major role in helping educators succeed. 


\section{NASA's Education Strategy}

NASA's education goals are tied to its overall operational plan and are stated in the NASA Education Strategic Coordination Framework. The Framework established three major educational goals with specified outcomes for 2006 and beyond (Table 1).

\section{Table 1. NASA Educational goals and expected outcomes. ${ }^{16}$}

\begin{tabular}{|l|l|}
\hline \multicolumn{2}{|c|}{ Goals } \\
\hline Strengthen NASA and the Nation's future workforce. & $\begin{array}{l}\text { Contribute to the development of the STEM workforce in } \\
\text { disciplines needed to achieve NASA's strategic goals } \\
\text { through a portfolio of investments. }\end{array}$ \\
\hline Attract and retain students in STEM disciplines. & $\begin{array}{l}\text { Attract and retain students in STEM disciplines through a } \\
\text { progression of educational opportunities for students, } \\
\text { teachers, and faculty. }\end{array}$ \\
\hline Engage Americans in NASA's mission. & $\begin{array}{l}\text { Build strategic partnerships and linkages between STEM } \\
\text { formal and informal education providers that promote } \\
\text { STEM literacy and awareness of NASA's mission. }\end{array}$ \\
\hline
\end{tabular}

All of these educational goals feed into NASA's overall agency mission "to pioneer the future in space exploration, scientific discovery, and aeronautics research." ${ }^{17}$ The Marshall Space Flight Center's Academic Affairs Office (AAO), in cooperation with the Exploration Launch Project's Integration Office, is developing curricula of various types to fulfill each of these goals.

NASA's Education Strategic Framework (Figure 3) specifies curricula that attempt to reach students on four levels:

- Inspire-Activities focused on promoting awareness of NASA's mission among the public, primarily through informal education and outreach activities.

- Engage - Education activities that incorporate participant interaction with NASA content in some manner for the purpose of developing a deeper understanding.

- Educate-Focused education support that promotes learning among targeted populations.

- Employ-Targeted development of

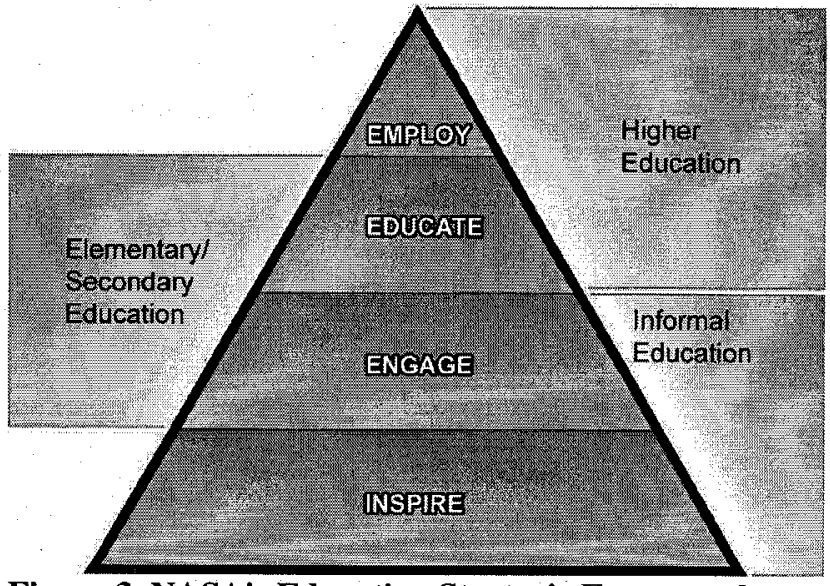

Figure 3. NASA's Education Strategic Framework. individuals who prepare for employment in disciplines needed to achieve NASA's mission and strategic goals. ${ }^{18}$

NASA has developed a wide range of educational experiences to achieve these various levels of involvement among its school-age constituents. Informal education products, designed to inspire or engage young people, are delivered primarily outside the classroom, targeting more informal learning organizations like museums, science centers, Scouting organizations, or Boys and Girls Clubs. Elementary and secondary education programs are classroom-based curricula that use NASA-related lessons and activities to teach students in grades K (kindergarten) through 12 about basic STEM principles. Higher education programs include advanced hands-on STEM activities, as well as internships and other research efforts designed to facilitate interested students' entry into STEM-related careers. 


\section{Current Outreach Efforts}

ELP, in cooperation with NASA's Education Office and MSFC's AAO, has developed strategies to reach targeted audiences with focused messages to develop interest in STEM among students from elementary schoolaged children through high school. An important part of this effort is also to educate students and their teachers on the many benefits derived from space-related activities.

In addition to traditional classroom course work, NASA is using or plans to use leading-edge, highly visible venues for sharing space exploration messages, including the Internet (via Web sites), podcasts, and live events. Through strategic partnerships with educational institutions and private industry, NASA is developing new, engaging methods of public outreach, such as interactive lunar mission electronic kiosks, videos for teachers and students, learning materials, podcasts, interactive educational games, and question-and-answer teleconferences with NASA engineers and scientists via NASA's Digital Learning Network (DLN). The DLN consists of a nationwide series of video teleconferences held at NASA's Educator Resource Centers (ERCs), one of which is located at U.S. Space and Rocket Center in Huntsville, AL. An interactive kiosk being developed in cooperation with industry partners will simulate an entire lunar mission, from rocket launch through the crew module's return to Earth.

To better understand the needs of educators, ELP is conducting focus groups with teachers at multiple grade levels to determine their needs and understand the most effective methods for teaching children and young people about space exploration. These sessions are already bearing fruit, as NASA has begun developing and modifying existing classroom materials based on teacher feedback to ensure the lessons are aligned with state and national standards and are implemented easily into classroom instruction. ELP has developed curriculum and classroom products that tie directly to NASA's strategic Global Exploration Strategy. These products, in turn, help meet the agency's and teachers' educational goals.

\section{A. Informal Learning Education Efforts (Inspire, Engage)}

\section{Simulation Tool / Rocket Building Tool}

With the widespread presence of electronic technologies, NASA is seeking to develop educational products that draw upon the popularity of these tools. One product NASA is developing is a detailed simulation program.

Originally used to help engineers simulate launch vehicle flight characteristics and ground support functions, this simulation is now being used for outreach purposes and is being investigated for educational applications as well. This might include driving a rover on the Moon or in search of specific rocks or geographical features or landing a vehicle on the Moon. With interactive "zooming," "panning," and interior view capabilities, the simulation allows users to view an animation of an entire International Space Station or lunar mission from any angle. Once available to educators, this simulation will provide students with a "hands-on" exploration experience.

Another demonstration tool NASA is developing is the Interactive Constellation Environment (ICE). The ICE consists of a large optical screen and interactive software that allows visitors to build and launch the Ares I crew launch vehicle and Ares $V$ cargo launch vehicle in a virtual environment (Figure 4). The exhibit highlights these spacecraft using digital animation, and demonstrates how the vehicles will interact in space. ICE is a large video screen with a motion-sensor interface. Individuals can use the interface to select and manipulate objects on the screen. In this case, the objects are elements of the Ares launch vehicles. Visitors select the vehicle they would like to construct and assemble it piece by piece to see how each intricate part comes together as well as learn the function of each component. After assembly, visitors can launch their rocket on its mission.

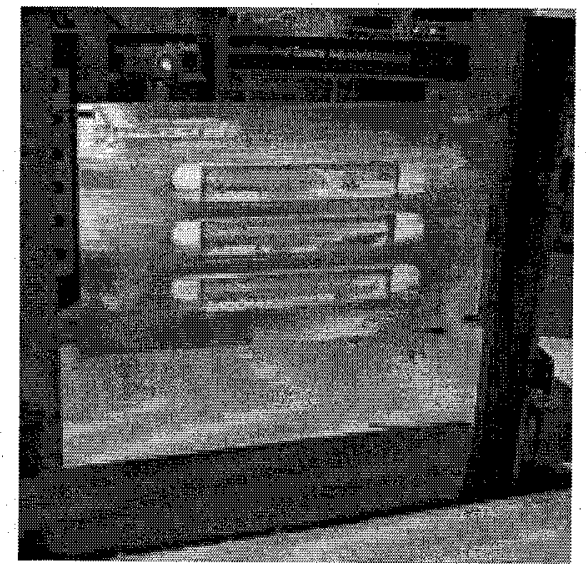

Figure 4. The ICE screen resembles technology shown in the science fiction film "Minority Report." 
Another important aspect of inspiring and engaging students is to provide them with real-world interactions with space-related science and technology.

NASA works closely with the Team America Rocketry Challenge (TARC), which is a contest for children in grades 7 through 12 . The specific objectives of the contest can vary slightly from year to year. In 2007, the goal was to build and fly a model rocket carrying one raw egg that achieves a precise flight duration of 45 seconds, reaches a precise altitude of 850 feet, and returns the egg without a crack. Robert M. Gates, Secretary of Defense; presented the prizes for this year's competition, demonstrating the importance of this competition to the nation's STEM education efforts. The top 25 teams at the TARC can qualify to participate in the Student Launch Initiative (SLI). ${ }^{19}$

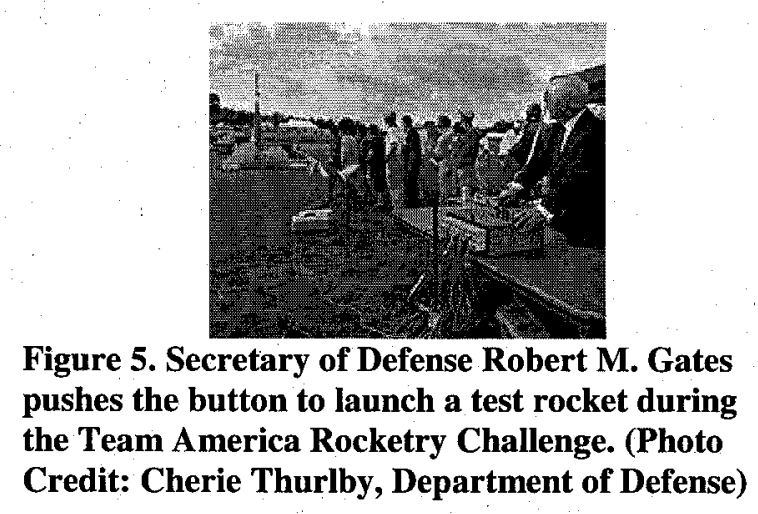

In addition to the Secretary of Defense, the Exploration Systems Mission Directorate (ESMD) at NASA Headquarters and the ELP Office had a presence at TARC. Dr. Scott Horowitz, Associate Administrator for ESMD, as well as Dan Dumbacher of the Engineering Directorate and the author spoke to the participants. Dr. Horowitz helped launch an Estes-built Ares I model rocket, while ground-based models of Ares I and Ares V were available for viewing and discussion to encourage interest in the Global Exploration Strategy.

The NASA Student Launch Initiative involves middle and high school students in designing, building, and testing reusable rockets with associated scientific payloads. This unique hands-on experience allows students to demonstrate proof-of-concept for their designs and makes previously abstract concepts tangible.

Both new and returning teams construct a vehicle that is designed to reach an altitude of 1 mile above ground level. In addition to actual vehicle performance, ELP engineers participate in teams' critical design reviews and flight readiness reviews teams via video teleconference, evaluating them on their design and other criteria. This educational experience culminates with a launch at MSFC in the spring. The TARC and SLI programs teach important lessons, not just in rocketry, but in dedication and teamwork.

\section{B. Elementary and Secondary Education (Engage, Educate)}

While many of the informal learning opportunities are facilitated directly by NASA personnel, the agency's role in elementary and secondary education is primarily curriculum development; though NASA educators also perform "teach the teacher" sessions when feasible. These sessions are conducted through the MSFC Academic Affairs Office at the U.S. Space and Rocket Center; through touring exhibits, like the Vision for Space Exploration trailer; and at conferences like Space 2007. The most popular courses these sessions train teachers on are the Engineering Design Challenges and FIRST Robotics, described below.

\section{Engineering Design Challenges $(E D C)$}

The Engineering Design Challenges (EDC) Program connects students in their classrooms with the challenges faced by NASA engineers as they design the next generation of space vehicles, habitats, and technologies. Middle and high school students work on design challenges with their teachers. These exercises help students achieve national goals in science, mathematics, and thinking skills. ${ }^{20}$ Working under the supervision of their teachers, students design, build, test, re-design, and re-build models that meet specified design criteria. Students employ the same analytical skills as engineers as they improve their designs. The design challenge culminates in the classroom, with each student team preparing a poster that describes the process and results of their work.

At present, MSFC is developing two expandable 7-week EDC courses, one related to thermal protection systems and the other discussing spacecraft structures. The content will educate students on thermal properties of 
materials and other aspects of thermodynamics, discussing the Ares launch vehicles and Orion Crew Exploration Vehicle as foundational information.

\section{Higher Education (Educate, Employ)}

In the field of higher education (college and post-graduate work), NASA has a wide variety of programs to facilitate the hiring of motivated young people into space-related careers. These efforts take two forms: 1) internship and 2) educational programs and hands-on activities.

The Higher Education team is responsible for involving the higher education community in NASA research and technology activities. NASA and MSFC provide numerous resources and opportunities for students and faculty of higher education institutions. Among these programs are:

\section{Hands-on Activities}

- Senior Projects / Student Internships - ELP is investigating opportunities for college-level seniors to participate in real-world projects connected to the Ares Launch Vehicles. Projects such as these would provide unpaid assistance to ELP and real-world, hands-on experience for graduating students in the science and engineering fields. These internships might include engineering trade studies for various aspects of the vehicles, which would relate to those worked on by project engineers.

- Great Moonbuggy Race - The Great Moonbuggy Race is held annually at the U.S. Space \& Rocket Center. Students are required to design a vehicle that addresses a series of engineering problems that are similar to problems faced by the original Moonbuggy team.

Each Moonbuggy is human powered and carries two students, one female and one male, over a half-mile simulated lunar terrain course including "craters," rocks, "lava" ridges, inclines and "lunar" soil.

Moonbuggy entries are expected to be "proof-of-concept" and engineering test models rather than final production models. Each student team of six members is responsible for building their own buggy, and the course drivers, who are chosen from each team, must also be builders of the vehicle.

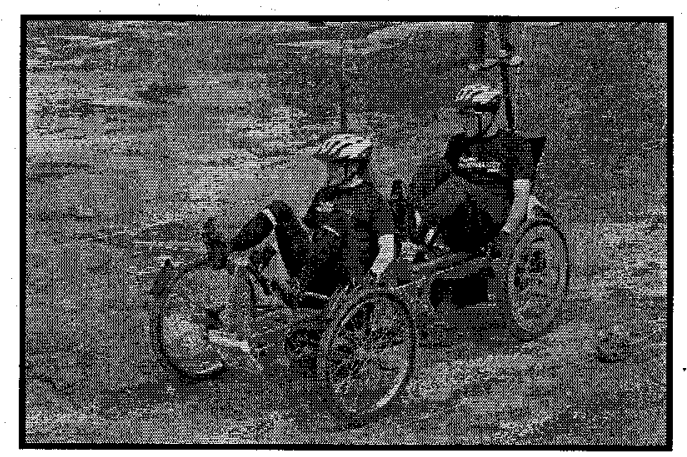

Students traverse a simulated lunar. landscape in the Great MoonbuggyRace.

As a part of the competition, and prior to course testing, the un-assembled Moonbuggy entries must be carried to the course starting line, with the unassembled components contained in a volume of 4 feet X 4 feet X 4 feet (dimension requirements similar to those for the original Lunar Roving Vehicle). At the starting line, the entries are assembled and readied for course testing and evaluated for safety. Assembly occurs one time prior to the first course run.

The top three winning teams in each division (one high school division and one college division) are those having the shortest total times in assembling their moonbuggies and traversing the terrain course. Each team is permitted two runs of the terrain course, and the shortest course time is added to the assembly time for the final total event time. The Moonbuggy Race emphasizes engineering design, teamwork, and competition.

- NASA University Student Launch Initiative - The NASA University Student Launch Initiative (USLI), an advanced version of SLI, involves college students in designing, building, and testing reusable rockets with associated scientific payloads. This unique hands-on experience allows students to demonstrate proof-ofconcept for their designs and gives previously abstract concepts tangibility.

The MSFC AAO, in partnership with the Alabama Space Grant Consortium and other Space Grant Consortia, manages this hands-on student rocketry design competition. In this project teams construct a vehicle designed to 
reach an altitude of 1 mile above ground level. In addition to actual vehicle performance, teams are also evaluated on design and other criteria. This educational experience culminates with a launch at MSFC in the spring.

The second year will begin in the summer of 2007 with a rocketry workshop at the University of Alabama in Huntsville (UAH), co-hosted by MSFC. Faculty and student teams will participate in the design, test and build phases at their home campuses. During the engineering phases the teams will undergo formal reviews (Preliminary Design Reviews, Critical Design Reviews, Flight Readiness Reviews, and Flight Hardware Check) by MSFC engineering panel members and local Huntsville Area Rocketry Association representatives. The project will culminate in the spring of 2008 with a launch competition held in Huntsville, AL. The Exploration Systems Mission Directorate at NASA Headquarters will fund this with $\$ 106,000$ in FY 2007, to which MSFC and Its partners add an additional $\$ 194,000$ for a total project value of $\$ 300,000$.

\section{Future Outreach Efforts}

In the future, NASA will create additional materials on a continuing basis, such as posters, fact sheets, games, and hands-on activities that attract the next generation to STEM. Additionally, ELP, in cooperation with Headquarters and other NASA Centers, is conducting more active public outreach efforts by providing engaging, well-informed speakers at local, regional, and national events such as science and technology trade shows, job fairs, and school activities not normally associated with space, such as college football games. Further inputs will be solicited from professional educators and students through focus groups and course evaluations of existing programs. Through this integrated, multimedia approach, ELP plans to reach students with engaging approaches that encourage them to take the educational steps they need to grow the nation's technical capabilities and to become excited about contributing to the next great frontier of space exploration.

\section{Conclusion}

The programs highlighted in this paper represent only a part of the efforts NASA's Exploration Launch Projects Office is making to inspire, engage, educate, and employ the science and technology workers of tomorrow. Additional information can be found at http://Www.nasa.gov/centers/marshall/education/index.html). Educating students in STEM disciplines is about more than just providing NASA with scientists, astronauts, and engineers: the nation as a whole benefits. Students educated in STEM will become tomorrow's doctors, nurses, chemists, scientists, programmers, and technology developers. ELP aims to be a leader in the quest to educate our nation's children by combining educational basics with new technologies and hands-on, inspiring experiences.

\section{References}

${ }^{1}$ Wallace, Kathryn. "America's Brain Drain Crisis: Why Our Best Scientists are Disappearing and What's Really at Stake." Readers Digest, December 2005.

2 "Educational Expenditure per Student." Education at a Glance 2006 Tables.

http://www.oecd.org/document/6/0,2340,en_2649_34515_37344774_1_1_1_1,00.html.

3 "Higher Education in Science and Engineering," Science and Engineering Indicators 2006. http://www.nsf.gov/statistics/seind06/c2/c2h.htm.

${ }^{4}$ National Aeronautics and Space Administration. Global Exploration Strategy Framework. 31 March 2007 http:/www.nasa.gov/home/hqnews/2007/may/HQ 07126 Exploration Framework.html.

${ }^{5}$ Karas, John. Keynote Address. Joint Army-Navy-NASA-Air Force (JANNAF) Conference, 15 May 2007.

${ }^{6}$ National Academy of Sciences. Rising Above The Gathering Storm: Energizing and Employing America for a Brighter Economic Future http://books.nap.edu/execsumm pdf/11463.pdf.

${ }^{7}$ Bureau of Labor Statistics.

${ }^{8}$ Futron Corporation. State of the Satellite Industry Report. June 2007

http://www.futron.com/pdf/resource center/reports/SIA 2006 Indicators.pdf.

${ }^{9} 1988$ Midwest Research Institute Report, "Economic Impact and Technological Progress of NASA Research and Development Expenditures, Volume 1, Executive Report.

${ }^{10}$ Griffin, Michael D. "Science and NASA." Goddard Space Flight Center http://www.nasa.gov/pdf/157382main_griffingoddard-science.pdf

${ }^{11}$ U.S. Chamber of Commerce. "Tapping America's Potential.” http://www.tap2015.org/.

12 Ibid.

${ }^{13}$ U.S. Department of Education. "10 Facts About Education Funding."

http:/www.ed.gov/about/overview/fed/10facts/index.html. 
${ }^{14}$ U.S. Department of Education. "The Facts About...Math Achievement." No Child Left Behind http://www.ed.gov/nclb/methods/math/math.pdf.

${ }^{15}$ National Science Foundation. "Higher Education in Science and Engineering," Science and Engineering Indicators 2006 http://www.nsf.gov/statistics/seind06/c2/c2h.htm.

${ }^{16}$ National Aeronautics and Space Administration. NASA Education Strategic.Coordination Framework: A Portfolio Approach. Washington, DC: NASA Headquarters Office of Education, 2006.

${ }^{17}$ Ibid.

${ }^{18}$ Ibid.

${ }^{19}$ NASA Student Launch Initiative (SLI). Marshall Space Flight Center Academic Affairs Office http://education.msfc.nasa.gov/docs/127.htm.

20 "Program Description." Engineering Design Challenges http://edc.nasa.gov/program.html.

\section{Acknowledgement}

The author would like to thank Bart Leahy; Sr. Technical Writer (Schafer Corporation) with the Office of Strategic Analysis and Communication, for his assistance in preparing this paper. 
MSFC-454-Presentation

\section{Educating and Inspiring} Young People for the Next: Generation of Exploration (j)

Robert C. Armstrong Deputy Manager Project Integration NASA Marshall Space Flight Center AIAA Joint Propulsion Conference July 2007 


\section{Agenda}

- The crisis in aerospace

- Impact of Science, Technology, Engineering, and Mathematics (STEM)Related Activities on U.S. Economy

- The Crisis in STEM Education

- NASA's Education Strategy

- Current Outreach Efforts

- Informal Learning Education Efforts

- Elementary and Secondary Education

- Higher Education

- Future Outreach Efforts

- Questions 


\section{The Crisis in Aerospace}

- NASA and its industry partners seek qualified future workers

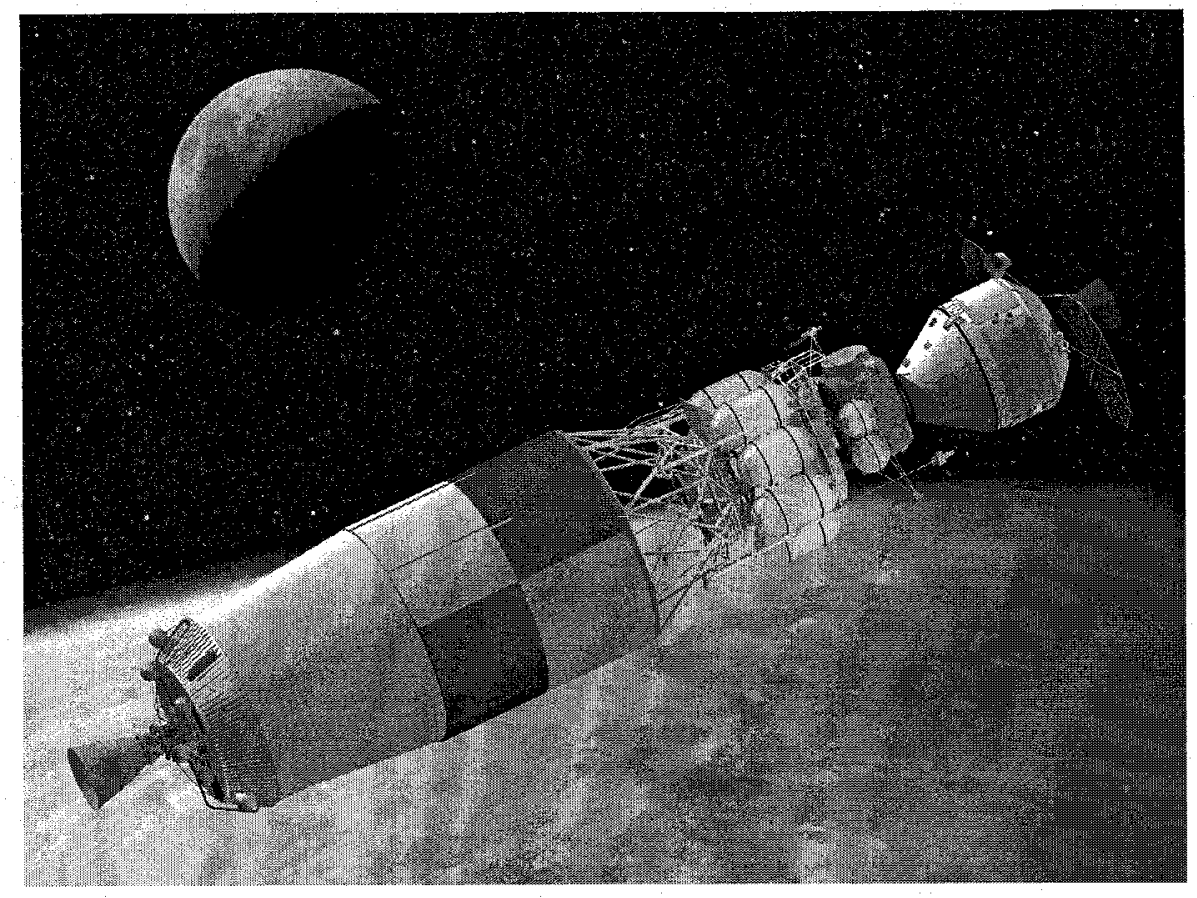

- The Vision for Space Exploration can be a springboard for inspiration

- More than just an agency problem: it is an impending national crisis

- Apollo missions inspired thousands of young people to enter technical fields

- Constellation Program can continue to provide motivation

- Numerous reports recognize problem:

- National Academies

- Committee on Economic Development

- Taskforce on the Future of American Innovation 


\section{The Impact}

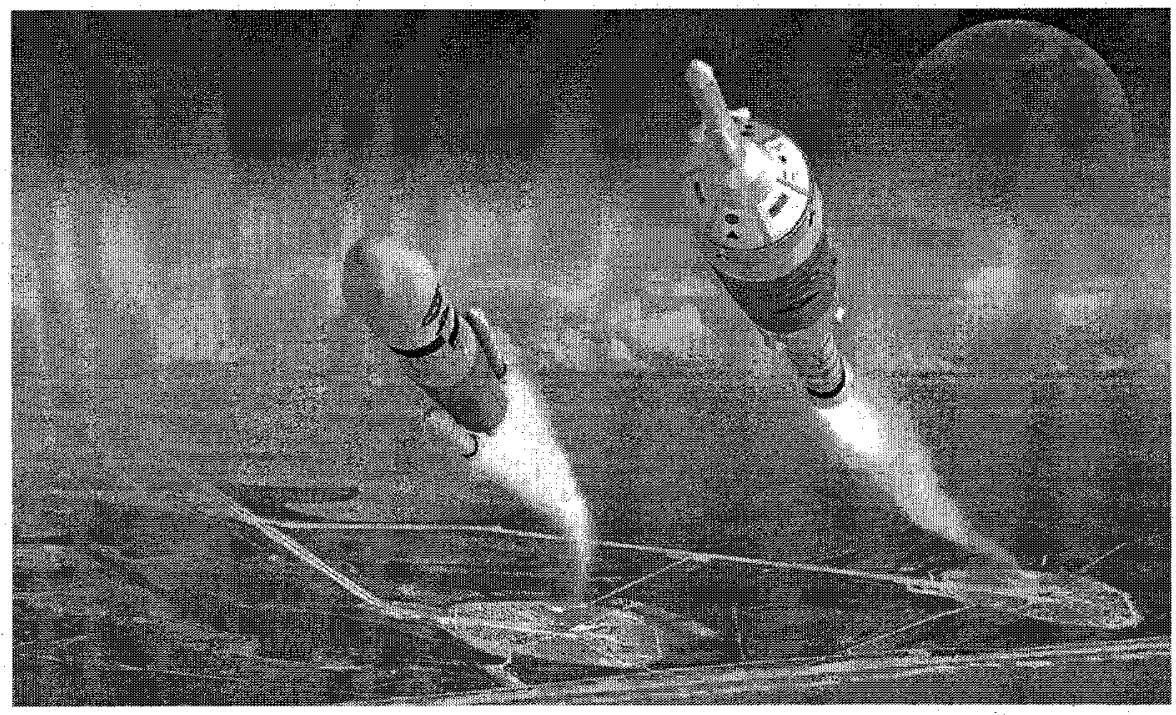

- As much as $\mathbf{8 5} \%$ of measured growth in U.S. income per capita was due to technological change

- $\approx 5$ percent of Americans engaged in science and engineering generate as much as 35 percent of U.S. exports

- "If I take the revenue in January and look again in December of that year $90 \%$ of my December revenue comes from products which were not there in January." - Craig Barrett, Chairman of the Intel Corporation

- The U.S. commercial space transportation business alone generated $\$ 98$ billion annually

- On average, each dollar spent on research and development (R\&D) returns about \$9 in technology-induced economic gain

- On average, each dollar spent on R\&D returns about $\$ 9$ in technology-induced economic gain.

- "Both [science and exploration] will contribute greatly to increased understanding of ourselves, the environment in which we live, and the solar system and universe around us." --NASA Administrator Michael Griffin 
- If current trends continue, by $\mathbf{2 0 1 0}$ more than 90 percent of all scientists and engineers in the world will be living in Asia

- South Korea, with one-sixth of our population, graduates as many engineers as the United States

- More than 50 percent of all engineering doctoral degrees awarded by U.S. engineering colleges are to foreign nationals

- Security concerns are reducing the number of foreign students available to study and work in the United States

- The number of engineering degrees awarded in the United States is down 20 percent from the peak year of 1985

- Although U.S. fourth graders score well against international competition, they fall near the bottom or dead last by 12th grade in mathematics and science, respectively

- All this is occurring despite the fact that total taxpayer investment in K-12 education in the United States for the 2004-2005 school year was estimated to be $\$ 536$ billion, exceeding national defense! 


\section{NASA's Education Strategy}

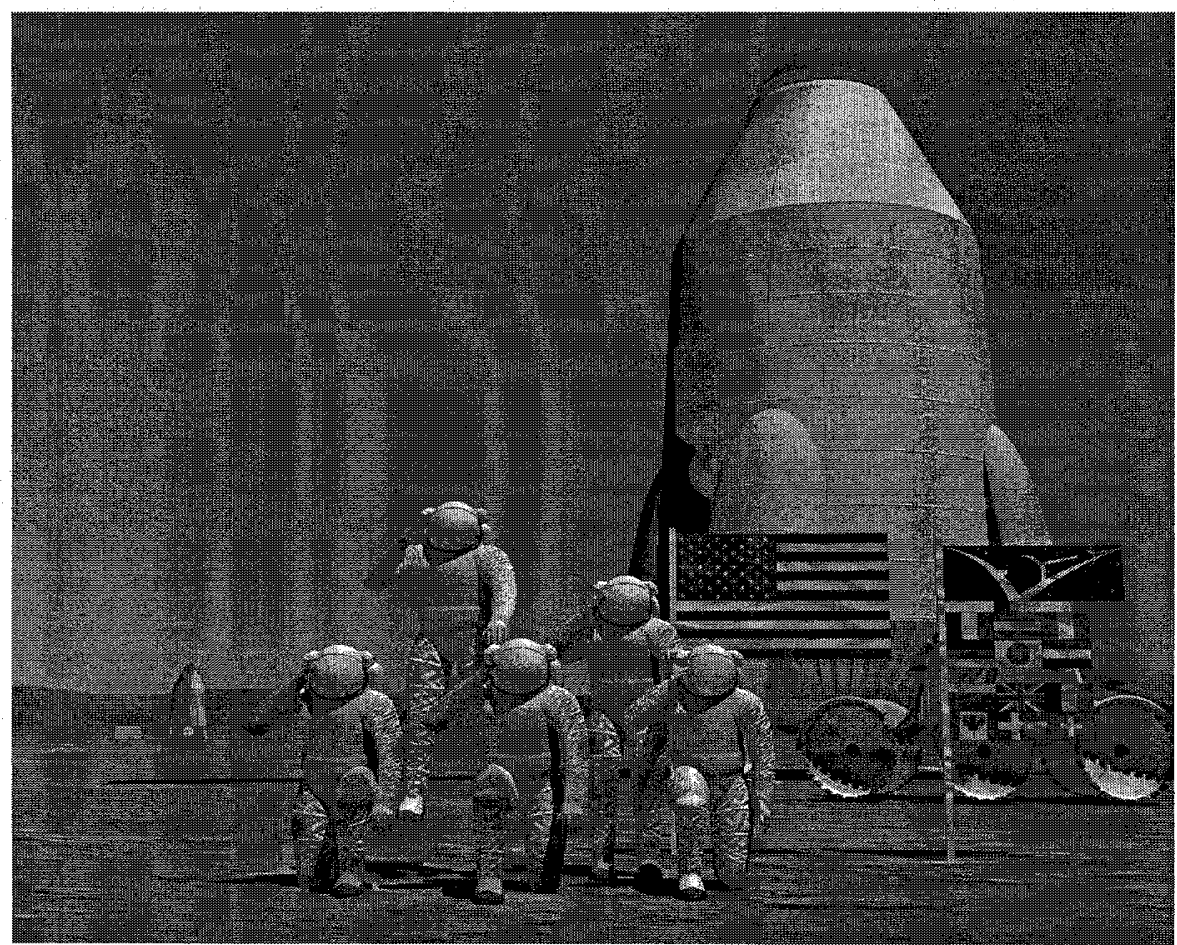

\section{Goals}

Strengthen NASA and the Nation's future workforce.

\begin{tabular}{|c|c|}
\hline Coals & Outcomes \\
\hline $\begin{array}{l}\text { Strengthen NASA and the } \\
\text { Nation's future workforce. }\end{array}$ & $\begin{array}{l}\text { Contribute to the development of the } \\
\text { STEM workforce in disciplines } \\
\text { needed to achieve NASA's strategic } \\
\text { goals through a portfolio of } \\
\text { investments. }\end{array}$ \\
\hline $\begin{array}{l}\text { Attract and retain students in } \\
\text { STEM disciplines. }\end{array}$ & $\begin{array}{l}\text { Attract and retain students in STEM } \\
\text { disciplines through a progression of } \\
\text { educational opportunities for } \\
\text { students, teachers, and faculty. }\end{array}$ \\
\hline $\begin{array}{l}\text { Engage Americans in NASA's } \\
\text { mission. }\end{array}$ & $\begin{array}{l}\text { Build strategic partnerships and } \\
\text { linkages between STEM formal and } \\
\text { informal education providers that } \\
\text { promote STEM literacy and } \\
\text { awareness of NASA's mission. }\end{array}$ \\
\hline
\end{tabular}

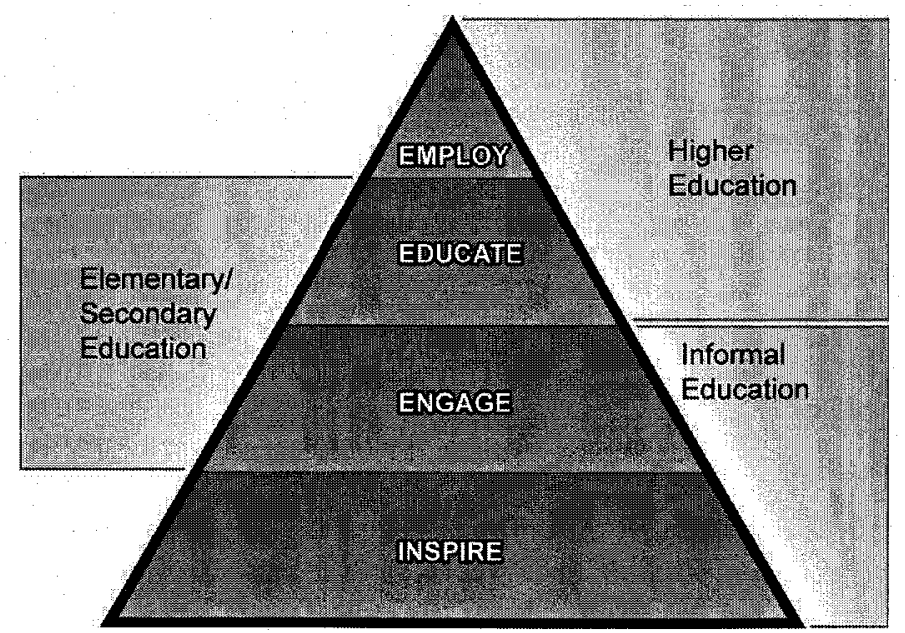

NASA's Education Strategic Framework. 


\section{ICON Demonstration}

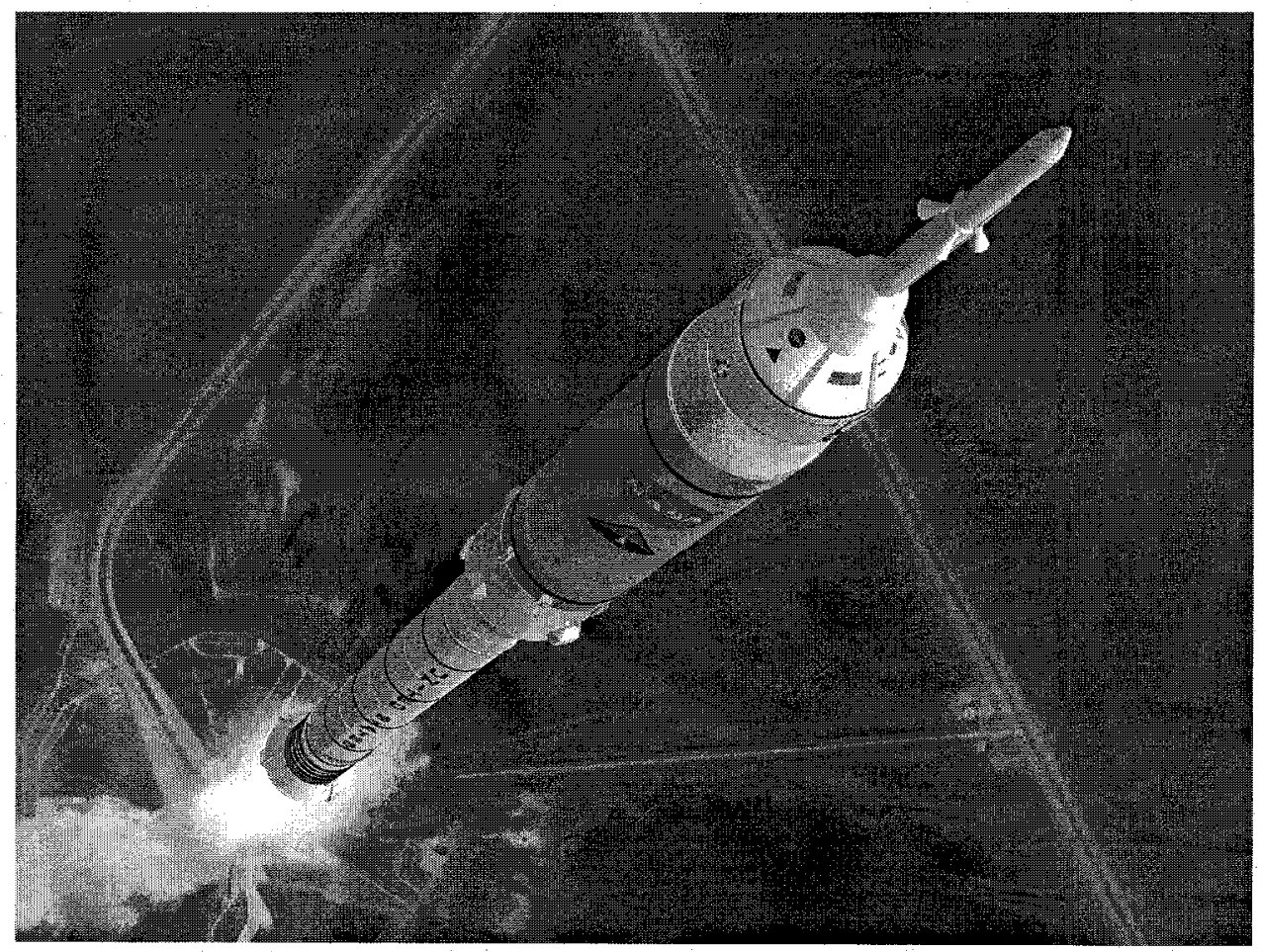




\section{NASA Outside the Classroom}

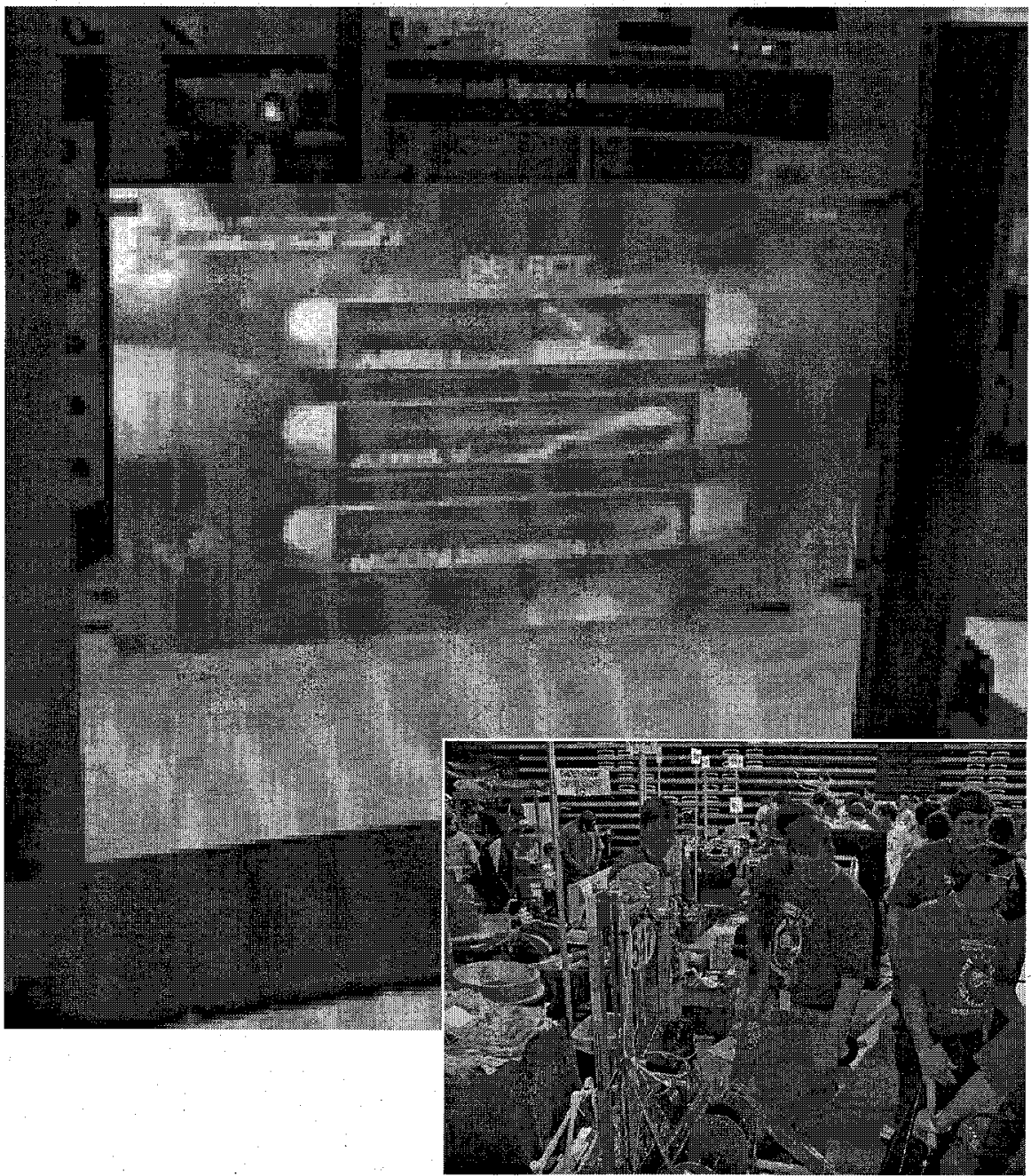

- Informal Learning Education Efforts (Inspire, Engage)

- ICON Simulation Tool / Rocket Building Tool

- NASA Student Launch Initiative (SLI) / Team America Rocketry Challenge

- Elementary and Secondary Education (Engage, Educate)

- Engineering Design Challenges (EDC)

- FIRST Robotics

- Higher Education (Educate, Employ)

- Internship and Educational Programs

- Hands-on Activities 


\section{Future Outreach Efforts}

- NASA will continue to create materials that attract the next

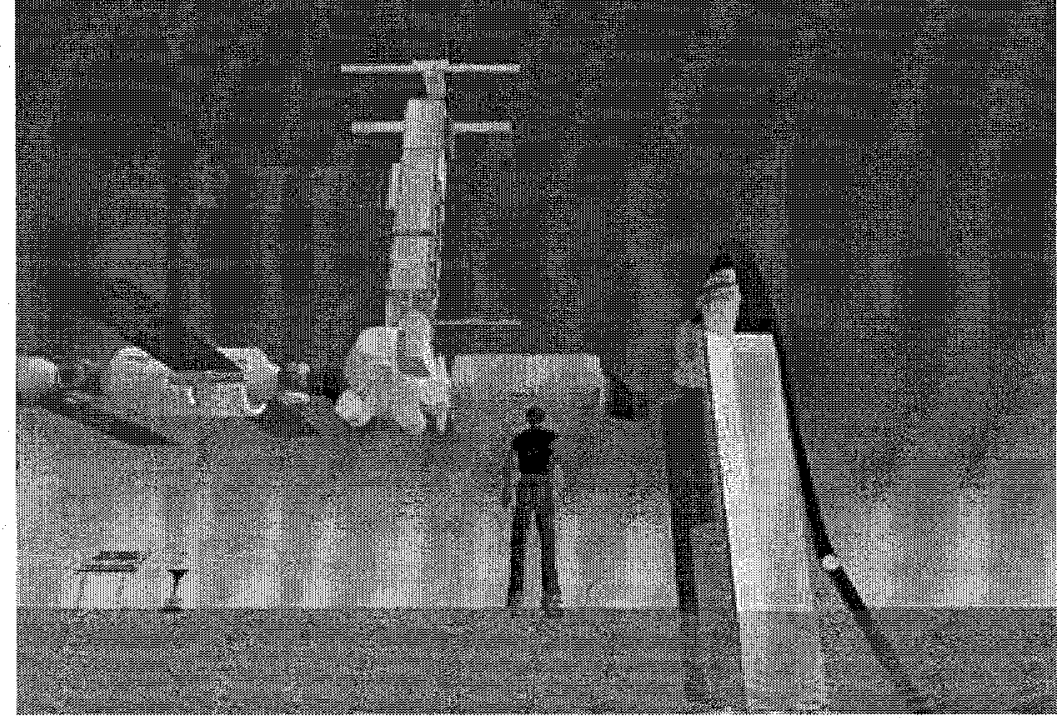

Image credit: Second Life / Linden Labs generation to STEM

- Conduct more public outreach efforts at school activities not normally associated with space, like football games

- Further inputs will be solicited from professional educators and students through focus groups and course evaluations

- Leverage new technologies to collaborate and inspire young people 


\section{Contact Information}

\section{Bob.Armstrong@NASA.Gov 256-544-1863}




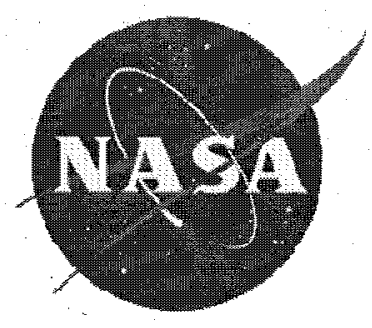

www. nasa.gov 